\title{
Clostridium difficile isolates with increased sporulation: emergence of PCR ribotype 002 in Hong Kong
}

\author{
V. C. C. Cheng • W. C. Yam • O. T. C. Lam • J. L. Y. Tsang • E. Y. F. Tse • \\ G. K. H. Siu • J. F. W. Chan • H. Tse • K. K. W. To • J. W. M. Tai • P. L. Ho • K. Y. Yuen
}

Received: 16 November 2010 / Accepted: 15 March 2011 /Published online: 6 April 2011

(C) The Author(s) 2011. This article is published with open access at Springerlink.com

\begin{abstract}
We identified a predominant clone of Clostridium difficile PCR ribotype 002, which was associated with an increased sporulation frequency. In 2009, 3,528 stool samples from 2,440 patients were tested for toxigenic $C$. difficile in a healthcare region in Hong Kong. A total of 345 toxigenic strains from 307 (13.3\%) patients were found. Ribotype 002 was the predominant ribotype, which constituted 35 samples from $29(9.4 \%)$ patients. The mean sporulation frequency of ribotype 002 was $20.2 \%$, which was significantly higher than that of the 56 randomly selected ribotypes other than 002 as concurrent controls $(3.7 \%, p<0.001)$. Patients carrying toxigenic ribotype 002 were more frequently admitted from an elderly home $(p=$ 0.01 ) and received more $\beta$-lactam antibiotics in the preceding 3 months compared with the controls $(p=0.04)$. The identification of toxigenic ribotype 002 in 2009 was temporally related to a significant increase in both the incidence of toxigenic $C$. difficile from 0.53 to 0.95 per 1,000 admissions $(p<0.001)$ and the rate of positive detection from $4.17 \%$ to $6.28 \%(p<0.001)$ between period 1 (2004-2008) and period 2 (2009). This finding should alert both the physician and the infection control team to the
\end{abstract}

V. C. C. Cheng • W. C. Yam • O. T. C. Lam • J. L. Y. Tsang •

E. Y. F. Tse $\cdot$ G. K. H. Siu • J. F. W. Chan $\cdot$ H. Tse $\cdot$ K. K. W. To

P. L. Ho $\cdot$ K. Y. Yuen

Department of Microbiology, Queen Mary Hospital,

Hong Kong Special Administrative Region, China

V. C. C. Cheng · J. W. M. Tai

Infection Control Team, Queen Mary Hospital,

Hong Kong Special Administrative Region, China

H. Tse $\cdot$ K. K. W. To $\cdot$ P. L. Ho $\cdot$ K. Y. Yuen $(\bowtie)$

Carol $\mathrm{Yu}$ Centre for Infection, The University of Hong Kong,

Hong Kong Special Administrative Region, China

e-mail: kyyuen@hkucc.hku.hk establishment of and possible outbreaks by ribotype 002 in our hospitals, as in the case of ribotype 027 .

\section{Introduction}

Clostridium difficile is an anaerobic, Gram-positive, sporeforming bacillus which causes gastrointestinal diseases ranging from antibiotic-associated diarrhea to pseudomembranous colitis. Though community-acquired infection can occur, most cases are found in the hospital and long-term care facilities [1]. The fecal colonization rate in ambulatory individuals is up to $2 \%[2,3]$ and this increased to $15-30 \%$ among hospitalized patients due to the acquisition from healthcare workers and the hospital environment [4]. About $15-60 \%$ of the colonized patients develop symptomatic diarrhea during hospitalization [5-7], which may increase the nosocomial transmission of $C$. difficile with hospital outbreaks. Recently, a virulent strain identified as PCR ribotype 027 , toxinotype III, or North American pulse-field type 1 has emerged to cause severe colitis, leading to a high mortality rate [8-10]. The mechanism of increased virulence is still under investigation, but it may be related to the 18-bp deletion and single-base-pair deletion at position 117 in the toxin regulator gene $(t c d C)$, leading to the hyperproduction of toxins $\mathrm{A}$ and $\mathrm{B}[11,12]$. In addition, increased sporulation frequency of certain epidemic strains of $C$. difficile PCR ribotype 027 may also contribute to its better survival and nosocomial spread [13, 14]. Sporulation occurs when the ability to maintain vegetative growth has failed and facilitates the transmission of $C$. difficile in the healthcare setting, as the spores remain infective and persist in the environment for many months [15].

A sporadic case of $C$. difficile PCR ribotype 027 was reported in Hong Kong in 2008 [16]. In response to this 
emerging infectious agent, further investigation was performed on all $C$. difficile isolates in a healthcare region in Hong Kong. We also conducted a retrospective review of the clinical and epidemiological data related to the different ribotypes of toxigenic $C$. difficile isolated in 2009. The findings and their potential implications in disease transmission and infection control practice are discussed.

\section{Materials and methods}

\section{Setting}

A surveillance program was conducted in a regional microbiology laboratory in Hong Kong. The laboratory provided service to a healthcare network of five hospitals, including one acute care university teaching hospital with 1,400 beds and four chronic care hospitals with 110 to 524 beds. The hospital network provided clinical service to a population of approximately 0.53 million people. Between 1 January 2009 and 31 December 2009, stool specimens from hospitalized patients sent for culture and cytotoxin assay of $C$. difficile were performed by our routine service protocol as usual, but the toxigenic strains were further characterized by molecular tests. The incidence of toxigenic $C$. difficile per 1,000 admissions and the rate of detection identified between period 1 (2004 and 2008) and period 2 (2009) were analyzed using databases of the laboratory information and hospital record system.

\section{Bacterial culture for $C$. difficile}

Liquid or semisolid stool samples were tested within $24 \mathrm{~h}$ of receipt. The samples were inoculated onto cycloserine-cefoxitin-fructose agar (CCFA) containing $4 \%$ proteose peptone, $0.5 \% \mathrm{Na}_{2} \mathrm{HPO}_{4}, 0.1 \% \mathrm{KH}_{2} \mathrm{PO}_{4}$, $0.01 \% \mathrm{MgSO}_{4}, 0.2 \% \mathrm{NaCl}, 0.6 \%$ fructose, $1.5 \%$ agar at pH 7.4 (\#CM0601, Oxoid, UK), with added selective supplement containing $250 \mathrm{mg} / \mathrm{L}$ D-cycloserine, $8 \mathrm{mg} / \mathrm{mL}$ cefoxitin (\#SR0096, Oxoid, UK), and 7\% horse blood. Culture plates were incubated anaerobically at $35^{\circ} \mathrm{C}$ to $37^{\circ} \mathrm{C}$ for $48 \mathrm{~h}$. Obligatory anaerobic, large Gram-positive bacilli that were isolated from the CCFA and were susceptible to $5 \mu \mathrm{g}$ of vancomycin were presumptively identified as $C$. difficile. The identification was confirmed by the Vitek ${ }^{\circledR}$ Anaerobe Identification Card (ANI) (bioMérieux, Inc., USA). Antimicrobial susceptibility testing against metronidazole, vancomycin, and ciprofloxacin were performed for selected strains using Etest strips according to the manufacturer's instructions (AB Biodisk, Sweden).
Cell culture cytotoxicity neutralization assay

Approximately 3 to $5 \mathrm{~g}$ of stool was suspended in $5 \mathrm{ml}$ of phosphate-buffered saline (PBS) in a 1:2 dilution at a $\mathrm{pH}$ level of 7. The sample was centrifuged at 3,000 rpm for 55 min to produce a supernatant, which was subsequently transferred into eppendorf tubes and centrifuged at $13,000 \mathrm{rpm}$ for $15 \mathrm{~min}$ at $4^{\circ} \mathrm{C}$ to clarify the supernatant. The supernatant was passed through a $0.22-\mu \mathrm{m}$-pore-size membrane filter. A toxin-producing $C$. difficile strain (UKEQAS QC 6109) was used as the positive control for the cell culture cytotoxicity neutralization assay (CCCNA), which was performed in sterile 96 -well plates coated with the HeLa cell line as previously described [16]. In addition to the direct detection of cytotoxin from stool filtrates, CCCNA was also performed on the stationary-phase culture supernatant of each $C$. difficile isolate. $C$. difficile isolates were subcultured to brain heart infusion broth and incubated anaerobically for $96 \mathrm{~h}$. Culture supernatant was subjected to CCCNA as for stool filtrate with the same interpretation criteria as previously described [16].

\section{PCR ribotyping}

DNA was extracted from $C$. difficile colonies using alkaline lysis as described previously [17]. Polymerase chain reaction (PCR) ribotyping was performed according to the method described by Bidet et al. [18]. After the electrophoresis of PCR products, the phylogenetic tree was constructed using BioNumerics v6.0 software (Applied Maths, Belgium).

slpA typing

$\operatorname{slp} A$ typing was performed for selected strains belonging to the same ribotype according to Joost et al. [19]. The purified PCR product was subjected to cycle sequencing by ABI BigDye terminator v1.1 (Applied Biosystems, Foster City, USA) and the resulting $\operatorname{slp} A$ sequence was compared to those in the NCBI database by using Nucleotide BLAST.

Aerotolerance sporulation experiment

The Miles and Misra method was adopted to study all PCR ribotype 002 isolates [20]. C. difficile was subcultured to $C$. difficile agar (Mast Group Ltd., Merseyside, UK) and incubated at $37^{\circ} \mathrm{C}$ anaerobically for $72 \mathrm{~h}$. Bacterial suspension was prepared in saline to a turbidity of McFarland standard 0.5 , followed by serial dilutions in saline to $10^{1}-10^{4}$. Twenty microliters of each bacterial suspension with dilutions from $10^{2}$ to $10^{4}$ were transferred to three sectors of 12 blood agar plates from a height of $2.5 \mathrm{~cm}$. The inoculum was spread over an area of 1.5-2.0 cm diameter. One set of agar plates (six blood agar plates) were incubated 
Fig. 1 Workup for Clostridium difficile PCR ribotype 002 in a healthcare region in Hong Kong (1 January 2009 to 31 December 2009). ${ }^{\mathrm{a}} 169$ strains from 145 patients were found to have cytotoxin production by cell culture cytotoxicity neutralization assay (CCCNA) from both stool filtrates and $C$. difficile isolates. Another 176 strains from 162 patients had negative cytotoxin production in stool filtrates but positive toxin production in the culture supernatant of $C$. difficile isolates

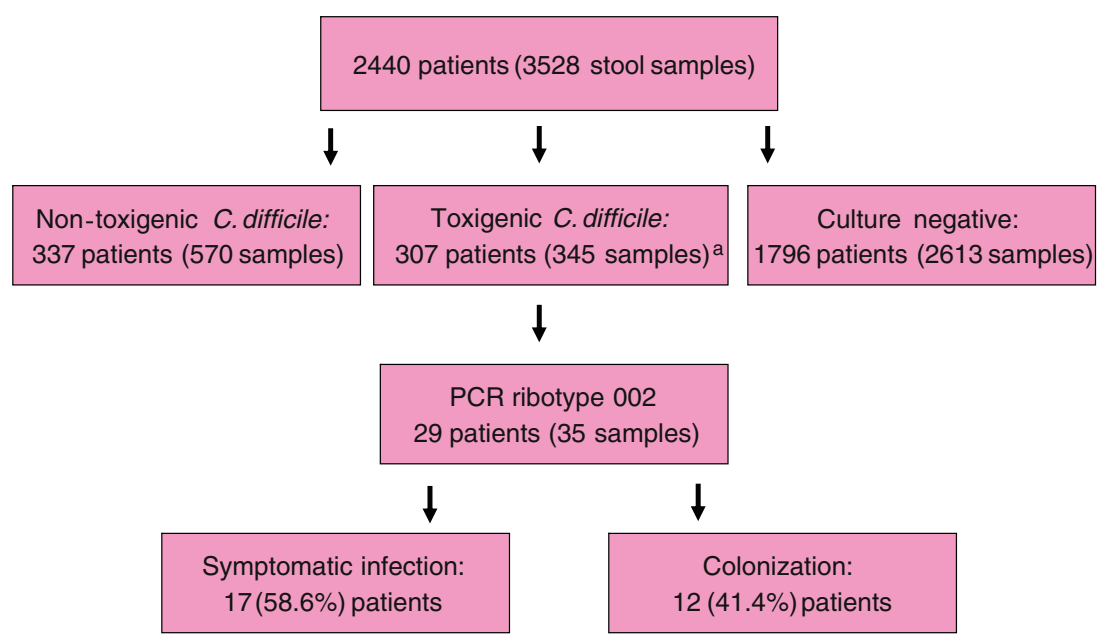

for $72 \mathrm{~h}$ at $37^{\circ} \mathrm{C}$ anaerobically and the other set of agar plates (six blood agar plates) were incubated for $48 \mathrm{~h}$ at $37^{\circ} \mathrm{C}$ aerobically, followed by a further incubation of $72 \mathrm{~h}$ at $37^{\circ} \mathrm{C}$ anaerobically. The sporulation frequency (the spore/total cell ratio), expressed as a percentage, was determined by dividing the average cell count of the second set over the first set. To rule out cross-contamination by other Clostridium species in the experiment [21], PCR for $C$. perfringens and $C$. difficile was performed on bacterial suspensions and colonies according to previously described methods [22, 23].

ELISA for the detection of $C$. difficile toxins A and B

Toxins $\mathrm{A}$ and $\mathrm{B}$ were measured by the $C$. difficile TOX A/B II $^{\text {TM }}$ kit (TechLab, the Netherlands), according to the manufacturer's instructions. All strains belonging to the PCR ribotype 002 were subcultured into brain heart infusion broth and incubated for $72 \mathrm{~h}$ anaerobically. Bacterial suspension was centrifuged at $3,000 \times \mathrm{g}$ for $10 \mathrm{~min}$ and $50 \mu \mathrm{l}$ of supernatant was mixed with $200 \mu \mathrm{l}$ of diluent supplied in the kit. One drop $(50 \mu \mathrm{l})$ of conjugate was added to the well of a microassay plate with immobilized affinitypurified polyclonal goat antibody against toxins $\mathrm{A}$ and $\mathrm{B}$. The $100 \mu$ l diluted sample was transferred and mixed with the conjugate in the wells. The plate was incubated at $37^{\circ} \mathrm{C}$ for $50 \mathrm{~min}$, washed four times with $1 \mathrm{X}$ wash solution, followed by the addition of $100 \mu \mathrm{l}$ substrate solution. Stop solution was added to terminate the reaction after $5 \mathrm{~min}$ of incubation at room temperature. The resulting yellow color change was quantified by measuring the optical density $450 \mathrm{~nm} / 620 \mathrm{~nm}$. An A450/620 value of 1.0 corresponded to $1 \mathrm{U}$ of the total amount of toxins (A and B).

Epidemiology of PCR ribotype 002 in our healthcare region

Patients with toxin-producing $C$. difficile were assessed by infection control nurses for symptomatology. Case records were reviewed if the patients had been discharged. Patients with diarrhea at the time of specimen collection were classified as having symptomatic infection, while those without diarrhea were classified as having asymptomatic colonization. Patients with symptomatic infection were further classified as having healthcare-associated infection, of which the development of symptoms started more than $48 \mathrm{~h}$ after admission to the hospital or within 4 weeks after discharge from the hospital, or community-associated infection, of which the development of symptoms started within $48 \mathrm{~h}$ after admission to the hospital or more than 12 weeks after discharge from the hospital, as previously described $[24,25]$. When symptoms developed 4-12 weeks after hospital discharge, the association was indeterminate. The disease severity was stratified according to a scoring system described previously [26]. Briefly, two points were given to

Table 1 Ribotype distribution of toxin-producing strains of Clostridium difficile among 307 patients in Hong Kong

\begin{tabular}{|c|c|c|}
\hline & $\begin{array}{l}\text { Total number of } \\
\text { strains (\%) }\end{array}$ & $\begin{array}{l}\text { Total number of } \\
\text { patients }(\%)\end{array}$ \\
\hline PCR ribotype $002^{\mathrm{a}}$ & $35(10.1 \%)$ & $29(9.4 \%)$ \\
\hline PCR ribotype og39 & $13(3.8 \%)$ & $11(3.6 \%)$ \\
\hline PCR ribotype 012 & $8(2.3 \%)$ & $7(2.3 \%)$ \\
\hline PCR ribotype 014 & $4(1.2 \%)$ & $4(1.3 \%)$ \\
\hline PCR ribotype 017 & $2(0.6 \%)$ & $2(0.7 \%)$ \\
\hline PCR ribotype 001 & $1(0.3 \%)$ & $1(0.3 \%)$ \\
\hline PCR ribotype 027 & 0 & 0 \\
\hline Other pattern & $242(70 \%)$ & $221(72 \%)^{\mathrm{c}}$ \\
\hline Non-typable & $40(11.6 \%)$ & $32(10.4 \%)$ \\
\hline Total & 345 & 307 \\
\hline
\end{tabular}

${ }^{\text {a }}$ PCR ribotype 002 constituted 55.6\% (35/63) of strains and 53.7\% (29/54) of patients with known ribotyping results

${ }^{\mathrm{b}}$ This cluster of strains was identified by slpA typing

${ }^{\mathrm{c}}$ Using $80 \%$ similarity in the dendrogram as the cutoff value, there were 106 distinct patterns with no more than eight isolates in each pattern 


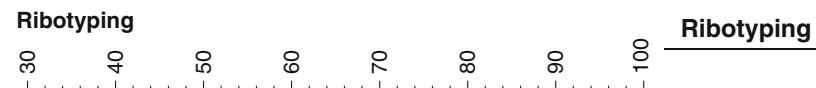

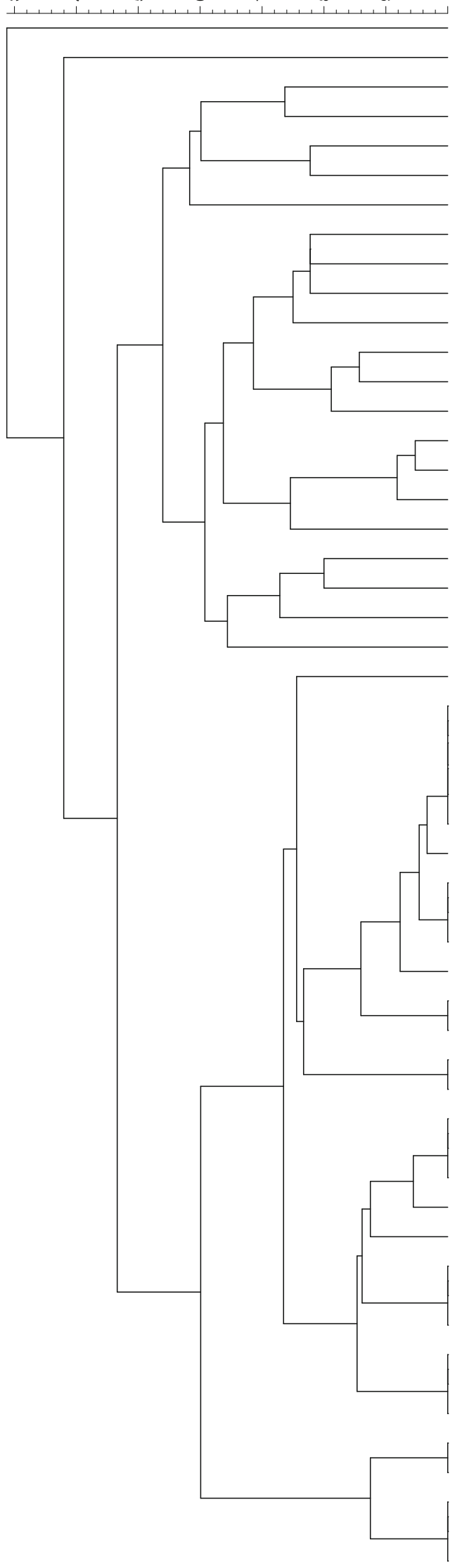

\section{||| ||}

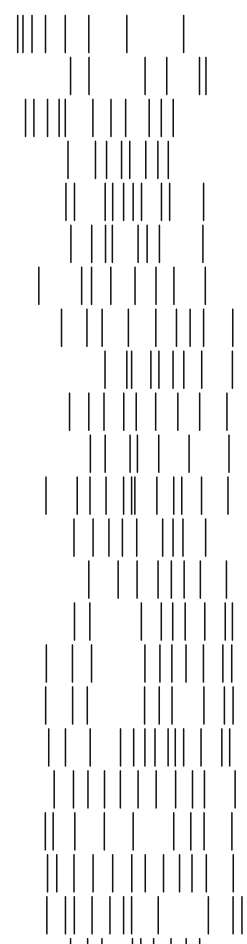

\|\|\|\|

$\| 1 \mid$

$\|||$

$|l| \mid$

$1|1|$

$\operatorname{lil} \mid 1$

|||| $\mid$

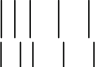

\|l | |

| || | ||

||| |

|l| |

l| | |

| | |

|l| |

|l| | |

|| | |

||||

|| ||

| || | ||

\|\|$\|$

\|\|$\|$

|l| |

||| || |

| || | ||

|| |

||

11
Marker

Standard Netherlands_117

Standard Netherlands_070

Standard Netherlands_078

Standard Netherlands_012

Standard Netherlands_029

Standard Netherlands_075

Standard Netherlands_023

Standard Netherlands_027

Standard Netherlands_081

Standard Netherlands_046

Standard Netherlands_001

Standard Netherlands_053

Standard Netherlands_087

Standard Netherlands_014

Standard Netherlands_077

Standard Netherlands_020

Standard Netherlands_095

Standard Netherlands_015

Standard Netherlands_017

Standard Netherlands_056

Standard Netherlands_003

Standard Netherlands_106

Standard Netherlands 002

229

398

531

610

536

171

538

386

330

412

457

445

486

092

384

424

476

339

147

570

473

113

149

213

586

628

535

580

627 
4 Fig. 2 Dendrogram of Clostridium difficile PCR ribotype 002 among 29 patients. Note: the strain number among 29 patients' isolates and the standard strains of different PCR ribotypes from the Netherlands are listed

patients with endoscopic confirmation of pseudomembranous colitis or those requiring intensive care support. One point each was given for age $>60$ years, temperature $>38.3^{\circ} \mathrm{C}$, albumin level $<2.5 \mathrm{mg} / \mathrm{dL}$, and peripheral $\mathrm{WBC}$ count $>15,000$ cells $/ \mathrm{mm}^{3}$ within $48 \mathrm{~h}$ of symptom onset. Patients with two points or more were considered as having "severe $C$. difficile-associated diarrhea (CDAD)". Otherwise, the patient was stratified as having " $C$. difficile infection". The demographics of the patients with $C$. difficile ribotype 002 and 56 randomly selected patients with PCR ribotypes other than 002 were compared.

Sporulation frequency and toxin level of $C$. difficile PCR ribotype 002

The toxin level of all strains of $C$. difficile PCR ribotype 002 were determined by ELISA. The sporulation frequency of $C$. difficile PCR ribotype 002 was measured by the quantitative method described above. The correlation between the sporulation frequency and toxin level was assessed. The sporulation frequencies and toxin levels of the strains isolated from patients with symptomatic infection were compared to those from asymptomatic patients. The sporulation frequency was tested in 56 randomly selected strains of PCR ribotypes other than 002 (one strain of 001 , six strains of 012 , three strains of 014, two strains of 017 , eight strains of og 39 , and 36 strains of other patterns) as the control.

\section{Statistical analysis}

Fisher's exact test and Student's $t$-test were used in the analysis, where appropriate. Changes in the incidence of toxigenic $C$. difficile per 1,000 admissions between period 1 (2004-2008) and period 2 (2009) was analyzed by Poisson regression. Correlation between sporulation frequency and toxin level was assessed by Spearman's rank correlation coefficient. All reported $p$-values were two-sided. A $p$-value of $<0.05$ was considered to be statistically significant. Computation was performed using the Statistical Package for the Social Sciences (SPSS) version 15.0 for Windows.

\section{Results}

Between 1 January 2009 and 31 December 2009, a total of 3,528 stool samples from 2,440 patients were tested for $C$. difficile culture and cytotoxin assay. A total of 169 samples from $145(5.9 \%)$ patients were found to have cytotoxin production by CCCNA from both stool filtrates and $C$. difficile isolates. Another 176 samples from 162 (6.6\%) patients had negative cytotoxin production in stool filtrates but positive toxin production in the culture supernatant of C. difficile isolates (Fig. 1). A total of 345 toxigenic $C$. difficile strains from $307(12.5 \%)$ patients were further tested for ribotyping and the results are listed in Table 1. All PCR ribotypes concurred with $\operatorname{slp} A$ typing results. PCR ribotype 002 was the most predominant ribotype, constituting 35 strains from $29(9.4 \%)$ patients with toxinproducing $C$. difficile. The dendrogram of $C$. difficile PCR ribotype 002 is shown in Fig. 2. All 35 strains of PCR ribotype 002 were resistant to ciprofloxacin (minimum inhibitory concentration $[\mathrm{MIC}]>32 \mu \mathrm{g} / \mathrm{ml})$. The $\mathrm{MIC}_{50}$ of metronidazole and vancomycin were $0.5 \mu \mathrm{g} / \mathrm{ml}$ and $0.75 \mu \mathrm{g} / \mathrm{ml}$, respectively, whereas the $\mathrm{MIC}_{90}$ were $0.75 \mu \mathrm{g} / \mathrm{ml}$ and $1.5 \mu \mathrm{g} / \mathrm{ml}$, respectively. The change in incidence of toxigenic $C$. difficile per 1,000 admissions and the rate of positive detection in our healthcare region from 2004 to 2009 are shown in Fig. 3. There was a significant increase in both the incidence of toxigenic $C$. difficile from 0.53 to 0.95 per 1,000 admissions $(p<0.001)$ and the rate of positive detection from $4.17 \%$ to $6.28 \%(p<0.001)$ between period 1 (2004-2008) and period 2 (2009).

Epidemiology of PCR ribotype 002 in our healthcare region

During the study period, a total of 29 patients shed $C$. difficile ribotype 002 in the stool. There were 20 males and 9 females, with a median age of 76 years (range 14-97 years). Eleven (37.9\%) patients were old age persons home residents. Symptomatic infection was diagnosed in 17 $(58.6 \%)$ patients, while ten of them had severe CDAD according to the scoring system (Table 2). All 17 patients with symptomatic infection were defined as healthcareassociated infection. Colonization of $C$. difficile was found in $12(41.4 \%)$ patients. Most of the patients $(24,82.8 \%)$ were managed in the medical ward, while three patients were managed in the surgical ward, one patient in the emergency department, and one patient in the pediatric and adolescent unit. These patients were located in 20 different wards from three different hospitals (one acute care and two chronic care hospitals) without any epidemiological linkage. There were five patients with repeated isolation of $C$. difficile during the same episode of hospitalization, among whom four patients had two episodes and one patient had three episodes. Among these five patients, three had symptomatic infection and one had asymptomatic colonization. The other progressed from asymptomatic colonization to symptomatic infection during hospitalization. The demographic characteristics of patients with $C$. difficile PCR ribotype 002 and ribotypes other than 002 are illustrated in Table 3. Patients carrying toxigenic $C$. difficile 
Fig. 3 Trend of isolation of toxigenic Clostridium difficile in a healthcare region in Hong Kong. Note: toxigenic Clostridium difficile isolation per 1,000 admissions in: period 1 (20042008): 0.53 vs. period 2 (2009): 0.95 ( $p$-value $<0.001$ ); Percentage of patients positive for toxigenic Clostridium difficile: period 1 (2004-2008): 4.17\% vs. period 2 (2009): $6.28 \%(p-$ value $<0.001)$

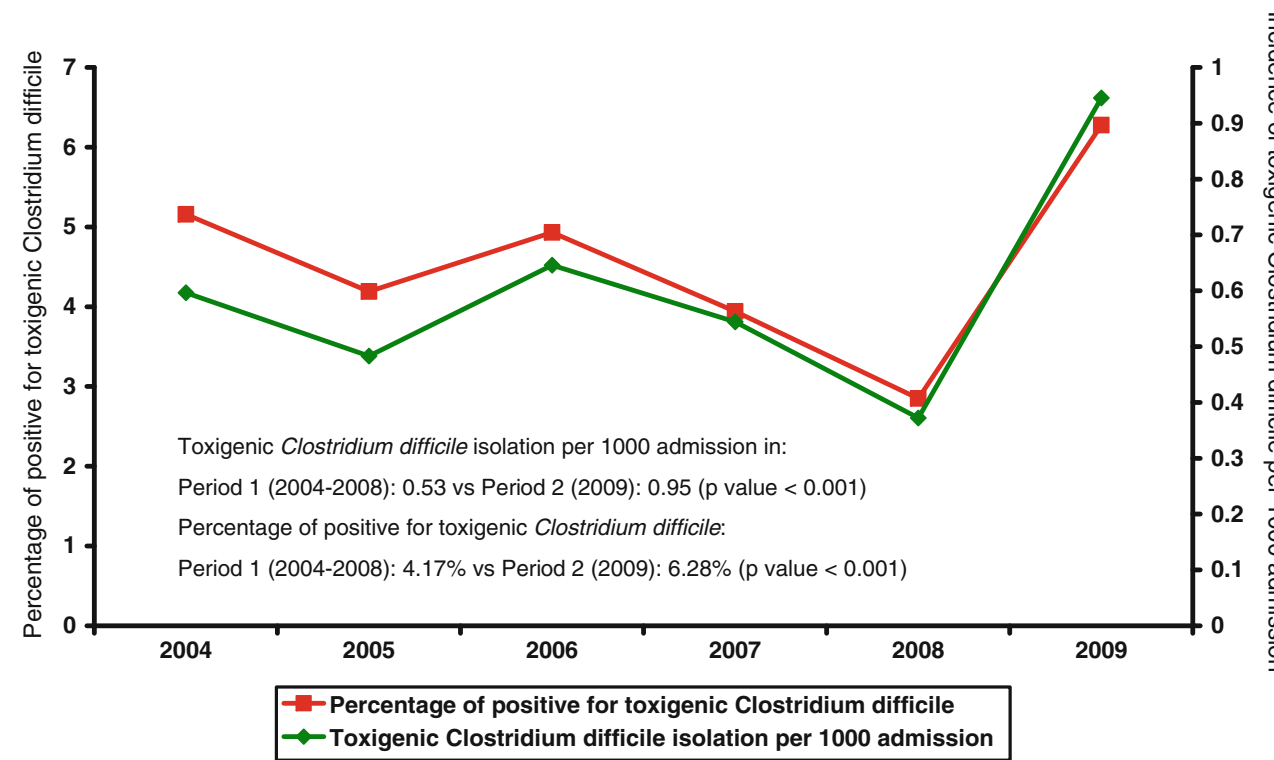

PCR ribotype 002 were more frequently admitted from an elderly home $(p=0.01)$ and received more $\beta$-lactam antibiotics in the preceding 3 months $(p=0.04)$.

Sporulation frequency and toxin level of $C$. difficile PCR ribotype 002

There is no statistically significant correlation between the sporulation frequency and the measured toxin levels of the C. difficile isolates (Spearman's rho 0.0311, $p=0.858$ ). The mean sporulation frequency of 35 strains of $C$. difficile PCR ribotype 002 was $20.2 \%$, which was significantly higher than that of the 56 randomly selected PCR ribotypes other than $002(3.7 \%, p<0.001)$. Among the 23 strains of $C$. difficile PCR ribotype 002 isolated from patients with symptomatic infection, the mean sporulation frequency was significantly higher than 12 strains of PCR ribotype 002 cultured from patients with asymptomatic colonization $(28.9 \%$ vs. $3.5 \%, p=0.02)$. The mean levels of toxin production by ELISA among strains collected from patients with asymptomatic colonization and symptomatic infection were $96.13 \mathrm{U} / \mathrm{ml}$ and $123.85 \mathrm{U} / \mathrm{ml}$, respectively $(p=0.29)$. Subgroup analysis for the $C$. difficile isolated from symptomatic patients with or without severe CDAD showed no statistically significant difference in terms of sporulation frequency and toxin production.

\section{Discussion}

C. difficile has become a re-emerging pathogen since the outbreak of a hypertoxigenic strain of PCR ribotype 027 in North America and Europe since 2003 [8, 10, 11]. This was followed by its global dissemination to the other continents in 2008 [27]. On the other hand, C. difficile PCR ribotypes other than 027 have also been increasingly reported recently. PCR ribotype 078 has been implicated in community-associated $C$. difficile infection in the Netherlands [24], while PCR ribotypes 001 and 018 were the most commonly identified ribotypes in the healthcare facilities in Germany, the UK, and Italy [28-30]. Although C. difficile ribotype 027 has also been reported in Hong Kong in 2008 [16], our present study showed that PCR ribotype 002 was the most predominant strain and constituted $56 \%$ (35 out of 63 typed strains with well-characterized PCR ribotyping) of the $C$. difficile strains isolated in 2009. This finding might explain the significant increase in the positive detection rate of toxigenic $C$. difficile and the incidence of toxigenic $C$. difficile per 1,000 admissions observed in 2009 as compared to the baseline data between 2004 and 2008.

C. difficile PCR ribotype 002 was commonly found in patients with both symptomatic infection and asymptomatic colonization. The mean sporulation frequency $(20 \%)$ of our strains was significantly higher than the other PCR ribotypes in our locality, but was comparable to that of the epidemic strains of $C$. difficile PCR ribotype 027 [13]. Since the epidemic strains of $C$. difficile were reported to have an inherently increased sporulation frequency $[13,31]$, and the transmission of $C$. difficile in the healthcare facilities was mediated primarily by spores found in the environment or carried by healthcare workers [32, 33], C. difficile PCR ribotype 002 might, thus, become an epidemic strain and contribute to hospital outbreaks. In fact, all 17 symptomatic patients carrying PCR ribotype 002 had healthcare-associated $C$. difficile infection. Furthermore, as the proportion of patients residing in elderly homes was significantly higher among those with PCR ribotype 002 than those with other ribotypes, further 


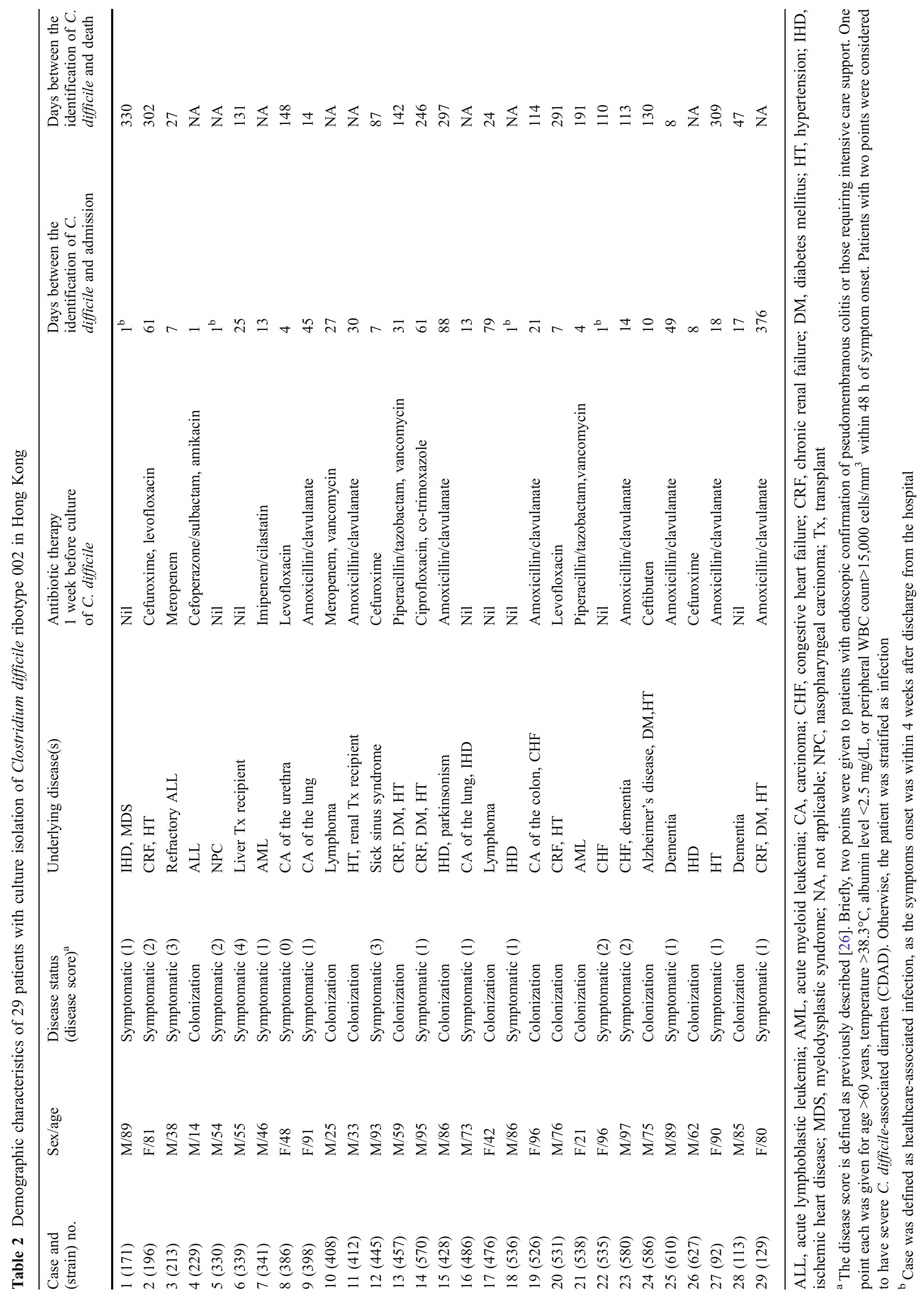


Table 3 Demographic characteristics of patients with culture isolation of Clostridium difficile ribotype 002 and non-ribotype 002 in Hong Kong

Clostridium difficile

ribotype $002(n=29)$
Clostridium difficile

ribotype other

than $002^{\mathrm{b}}(n=56)$

\begin{tabular}{|c|c|c|c|}
\hline Age $($ mean $\pm \mathrm{SD})$ & $68.1 \pm 25.5$ & $58.3 \pm 26.2$ & 0.97 \\
\hline $\operatorname{Sex}(M / F)$ & $20 / 9$ & $33 / 23$ & 0.37 \\
\hline Residence in elderly home & $11(37.9 \%)$ & $7(12.5 \%)$ & $0.01^{\mathrm{a}}$ \\
\hline \multicolumn{4}{|l|}{ Patients with } \\
\hline Malignancy & $12(41.4 \%)$ & $20(35.7 \%)$ & 0.61 \\
\hline Organ transplant & $2(6.9 \%)$ & $5(8.9 \%)$ & 1.0 \\
\hline Cardiopulmonary condition & $9(31.0 \%)$ & $10(17.9 \%)$ & 0.18 \\
\hline Renal failure & $5(17.2 \%)$ & $7(12.5 \%)$ & 0.55 \\
\hline Cerebrovascular accident & $5(17.2 \%)$ & $6(10.7 \%)$ & 0.40 \\
\hline Diabetes mellitus & $4(13.8 \%)$ & $9(16.1 \%)$ & 0.78 \\
\hline \multicolumn{4}{|l|}{ Patients with } \\
\hline Asymptomatic colonization & $12(41.4 \%)$ & $26(46.4 \%)$ & 0.66 \\
\hline Severe $\mathrm{CDAD}^{\mathrm{c}}$ & $7 / 17(41.2 \%)$ & $13 / 30(43.3 \%)$ & 0.90 \\
\hline $\begin{array}{l}\text { Number of hospitalizations in } \\
\text { the past year, median (interquartile range) }\end{array}$ & $6(4-12)$ & $5.5(2-12.75)$ & 0.52 \\
\hline $\begin{array}{l}\text { Number of patients with isolation of toxigenic } \\
\text { C. difficile in the past year }\end{array}$ & $3(10.3 \%)$ & $8(14.3 \%)$ & 0.74 \\
\hline \multicolumn{4}{|l|}{$\begin{array}{l}\text { Days of antibiotics }{ }^{\mathrm{d}} \text { received by patients in } \\
\text { the past } 3 \text { months }(\text { mean } \pm \text { SD) }\end{array}$} \\
\hline$\beta$-lactams & $23.7 \pm 17.9$ & $16.2 \pm 14.6$ & 0.04 \\
\hline Fluoroquinolones & $2.6 \pm 5.1$ & $5.6 \pm 10.0$ & 0.14 \\
\hline Clindamycin & 0 & $0.2 \pm 1.2$ & 0.35 \\
\hline \multicolumn{4}{|l|}{ Number of patients using proton pump inhibitors } \\
\hline Within 90 days & $14(48.3 \%)$ & $19(33.9 \%)$ & 0.24 \\
\hline 91-180 days & $8(27.6 \%)$ & $12(21.4 \%)$ & 0.59 \\
\hline $181-365$ days & $5(17.2 \%)$ & $10(17.9 \%)$ & 1 \\
\hline $\begin{array}{l}\text { Mean (range) days between the identification } \\
\text { of } C \text {. difficile and admission }\end{array}$ & $35.2(1-376)$ & $31.4(0-416)$ & 0.99 \\
\hline $\begin{array}{l}\text { 30-day survival after the identification of } \\
\text { C.difficile and admission }\end{array}$ & $3(10.3 \%)$ & $6(10.7 \%)$ & 0.96 \\
\hline
\end{tabular}

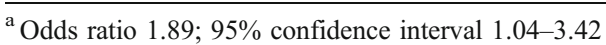

${ }^{\mathrm{b}}$ Patients with Clostridium difficile ribotype $001(n=1), 012(n=6), 014(n=3), 017(n=2), \operatorname{og} 39(n=8)$, and unrecognized ribotype $(n=36)$ were randomly selected as the control

${ }^{\mathrm{c}}$ Severe CDAD (C. difficile-associated diarrhea) is defined according to the disease score, as previously described [26]

${ }^{\mathrm{d}}$ Penicillin group included ampicillin, amoxicillin-clavulanate, ampicillin-sulbactam, ticarcillin-clavulanate, piperacillin, and piperacillin-tazobactam; cephalosporin group included cefazolin, cefuroxime, cefotaxime, ceftriaxone, ceftazidime, cefoperazone, cefoperazone-sulbactam, cefepime; carbapenem group included imipenem-cilastatin, meropenem, and ertapenem; fluoroquinolones included ciprofloxacin, levofloxacin, and moxifloxacin

investigations should be conducted in order to determine whether elderly homes might serve as an epidemic center amplifying this particular ribotype in our locality.

Interestingly, $C$. difficile PCR ribotype 002 isolated from patients with symptomatic infection had a significantly higher rate of sporulation, but not to the level of toxin production in vitro. Furthermore, there was no correlation between toxin production and sporulation. Our finding was in concordance with a recent study which suggested toxin production and sporulation to be opposite survival strategies for $C$. difficile in response to nutrient limitation by demonstrating an inverse correlation between toxin level and spore count in stationary-phase cultures [34]. However, a more recent analysis of a hypervirulent strain of $C$. difficile exhibited an increased sporulation as well as toxin production [14]. Since sporulation and toxin production is a complex process [35], and the disease severity of $C$. difficile is also determined by host factors such as the age, 
underlying diseases, and levels of toxin-neutralizing antibodies [36, 37], the relationship between sporulation frequency and disease severity remains to be elucidated.

The emergence of $C$. difficile with an inherently increased sporulation such as PCR ribotypes 027, 001, and 002 poses a great challenge to the infection control team. There is increasing evidence that the use of fluoroquinolones is a major risk factor for CDAD in the hospital and long-term care facilities [38-42]. Similar to the other emerging PCR ribotypes of $C$. difficile, all of our ribotype 002 strains were resistant to fluoroquinolones with an $\mathrm{MIC}>32 \mu \mathrm{g} / \mathrm{ml}$ against ciprofloxacin. Since the use of fluoroquinolones is increasing globally and locally [43, 44], our antimicrobial stewardship program should no longer target broad-spectrum antimicrobial agents only and should extend to include fluoroquinolones as well $[45,46]$. Of note, patients carrying $C$. difficile PCR ribotype 002 were more frequently found to have used $\beta$-lactam antibiotics, including penicillin, cephalosporin, and carbapenem, in the preceding 3 months to our analysis (Table 3 ). As most of the $\beta$-lactams have a relatively lower MIC against $C$. difficile [47-49], strains with inherently increased sporulation, such as PCR ribotype 002, may survive better than poorly sporulating ribotypes, despite $\beta$-lactam antibiotics therapy. The waterless alcohol-based hand rub, which has been highly advocated in the healthcare setting for hand hygiene, was not effective against the spores of $C$. difficile in the hands [50,51], even with directly observed hand hygiene practice [52]. Therefore, a timely laboratory diagnosis to recognize this high-risk strain would facilitate strategic infection control interventions, which should include the early identification of symptomatic cases for contact precautions with single-room isolation and thorough environmental cleaning with chlorine-based germicides in order to inactivate $C$. difficile spores. In fact, the use of nonchlorine-based cleaning agents has been associated with a paradoxical increase in sporulation, which may further enhance the nosocomial transmission of $C$. difficile [31, 53]. A close collaboration between the microbiology laboratory and the infection control team is essential for the successful prevention of nosocomial outbreaks of $C$. difficile PCR ribotype 002 in our healthcare region.

There were several limitations to this study. Firstly, as there was no standardized guideline on when to order stool testing for $C$. difficile in our hospital, the population of our samples may have been biased. This might contribute to the apparently higher proportion of asymptomatic colonization of ribotype 002 among our population than that previously reported for $C$. difficile in general [2-4]. However, the exact asymptomatic colonization rate of ribotype 002 has not been clearly documented elsewhere. Secondly, we only had $23(20 \%)$ out of 116 control strains available for the full panel of PCR ribotyping [54]. There might be a possibility of missing some important PCR ribotypes in our series. However, among 221 patients with unrecognized PCR ribotypes, there were 106 distinct patterns and no major cluster. Thirdly, we could not retrieve the archived strain from the early period and, thus, the origin of this $C$. difficile PCR ribotype 002 could not be ascertained. From the epidemiological perspective, the incidence of toxigenic $C$. difficile remained static ( 0.53 per 1,000 admissions) between 2004 and 2008, but it suddenly increased to 0.95 per 1,000 admissions in 2009. Although the incidence was lower than some centers in Europe and was still within an acceptable limit of less than 5 cases per 1,000 admissions as recommended by some experts $[55,56]$, an $80 \%$ upsurge should alert both the physician and the infection control team to possible outbreaks of ribotype 002 before it could become established in our hospitals, as in the case of $C$. difficile PCR ribotype 027.

Acknowledgment We thank Dr. E.J. Kuijper (Leiden University, the Netherlands) for providing us the standard strains of $C$. difficile PCR ribotypes used as the positive control. The work was supported by the Research Fund for the Control of Infectious Diseases (RFCID) of the Food and Health Bureau (FHB) of the Hong Kong SAR Government.

Open Access This article is distributed under the terms of the Creative Commons Attribution Noncommercial License which permits any noncommercial use, distribution, and reproduction in any medium, provided the original author(s) and source are credited.

\section{References}

1. Fawley WN, Wilcox MH (2001) Molecular epidemiology of endemic Clostridium difficile infection. Epidemiol Infect 126:343-350

2. Aronsson B, Möllby R, Nord CE (1985) Antimicrobial agents and Clostridium difficile in acute enteric disease: epidemiological data from Sweden, 1980-1982. J Infect Dis 151:476-481

3. Viscidi R, Willey S, Bartlett JG (1981) Isolation rates and toxigenic potential of Clostridium difficile isolates from various patient populations. Gastroenterology 81:5-9

4. Barbut F, Petit JC (2001) Epidemiology of Clostridium difficileassociated infections. Clin Microbiol Infect 7:405-410

5. Samore MH, DeGirolami PC, Tlucko A, Lichtenberg DA, Melvin ZA, Karchmer AW (1994) Clostridium difficile colonization and diarrhea at a tertiary care hospital. Clin Infect Dis 18:181-187

6. Johnson S, Clabots CR, Linn FV, Olson MM, Peterson LR, Gerding DN (1990) Nosocomial Clostridium difficile colonisation and disease. Lancet 336:97-100

7. McFarland LV, Mulligan ME, Kwok RY, Stamm WE (1989) Nosocomial acquisition of Clostridium difficile infection. $\mathrm{N}$ Engl $\mathrm{J}$ Med 320:204-210

8. Loo VG, Poirier L, Miller MA, Oughton M, Libman MD, Michaud S, Bourgault AM, Nguyen T, Frenette C, Kelly M, Vibien A, Brassard P, Fenn S, Dewar K, Hudson TJ, Horn R, René P, Monczak Y, Dascal A (2005) A predominantly clonal multi-institutional outbreak of Clostridium difficile-associated diarrhea with high morbidity and mortality. N Engl J Med 353:2442-2449

9. Miller M, Gravel D, Mulvey M, Taylor G, Boyd D, Simor A, Gardam M, McGeer A, Hutchinson J, Moore D, Kelly S (2010) 
Health care-associated Clostridium difficile infection in Canada: patient age and infecting strain type are highly predictive of severe outcome and mortality. Clin Infect Dis 50:194-201

10. Pépin J, Valiquette L, Alary ME, Villemure P, Pelletier A, Forget K, Pépin K, Chouinard D (2004) Clostridium difficile-associated diarrhea in a region of Quebec from 1991 to 2003: a changing pattern of disease severity. CMAJ 171:466-472

11. Warny M, Pepin J, Fang A, Killgore G, Thompson A, Brazier J, Frost E, McDonald LC (2005) Toxin production by an emerging strain of Clostridium difficile associated with outbreaks of severe disease in North America and Europe. Lancet 366:1079-1084

12. Wolff D, Brüning T, Gerritzen A (2009) Rapid detection of the Clostridium difficile ribotype $027 \mathrm{tcd} C$ gene frame shift mutation at position 117 by real-time PCR and melt curve analysis. Eur J Clin Microbiol Infect Dis 28:959-962

13. Akerlund T, Persson I, Unemo M, Norén T, Svenungsson B, Wullt M, Burman LG (2008) Increased sporulation rate of epidemic Clostridium difficile Type 027/NAP1. J Clin Microbiol 46:1530 1533

14. Merrigan M, Venugopal A, Mallozzi M, Roxas B, Viswanathan VK, Johnson S, Gerding DN, Vedantam G (2010) Human hypervirulent Clostridium difficile strains exhibit increased sporulation as well as robust toxin production. J Bacteriol 192:49044911

15. Verity P, Wilcox MH, Fawley W, Parnell P (2001) Prospective evaluation of environmental contamination by Clostridium difficile in isolation side rooms. J Hosp Infect 49:204-209

16. Cheng VC, Yam WC, Chan JF, To KK, Ho PL, Yuen KY (2009) Clostridium difficile ribotype 027 arrives in Hong Kong. Int $\mathbf{J}$ Antimicrob Agents 34:492-493

17. Yam WC, Yuen KY, Kam SY, Yiu LS, Chan KS, Leung CC, Tam CM, Ho PO, Yew WW, Seto WH, Ho PL (2006) Diagnostic application of genotypic identification of mycobacteria. J Med Microbiol 55:529-536

18. Bidet P, Lalande V, Salauze B, Burghoffer B, Avesani V, Delmée M, Rossier A, Barbut F, Petit JC (2000) Comparison of PCRribotyping, arbitrarily primed PCR, and pulsed-field gel electrophoresis for typing Clostridium difficile. J Clin Microbiol 38:2484-2487

19. Joost I, Speck K, Herrmann M, von Müller L (2009) Characterisation of Clostridium difficile isolates by $\operatorname{slp} A$ and $t c d C$ gene sequencing. Int J Antimicrob Agents 33(Suppl 1):S13-S18

20. Hedges AJ, Shannon R, Hobbs RP (1978) Comparison of the precision obtained in counting viable bacteria by the spiral plate maker, the droplette and the Miles \& Misra methods. J Appl Bacteriol 45:57-65

21. Paredes-Sabja D, Bond C, Carman RJ, Setlow P, Sarker MR (2008) Germination of spores of Clostridium difficile strains, including isolates from a hospital outbreak of Clostridium difficile-associated disease (CDAD). Microbiology 154:22412250

22. Persson S, Torpdahl M, Olsen KE (2008) New multiplex PCR method for the detection of Clostridium difficile toxin A $(t c d A)$ and toxin $\mathrm{B}(t c d B)$ and the binary toxin $(c d t A / c d t B)$ genes applied to a Danish strain collection. Clin Microbiol Infect 14:1057-1064

23. Wu J, Zhang W, Xie B, Wu M, Tong X, Kalpoe J, Zhang D (2009) Detection and toxin typing of Clostridium perfringens in formalin-fixed, paraffin-embedded tissue samples by PCR. J Clin Microbiol 47:807-810

24. Goorhuis A, Bakker D, Corver J, Debast SB, Harmanus C, Notermans DW, Bergwerff AA, Dekker FW, Kuijper EJ (2008) Emergence of Clostridium difficile infection due to a new hypervirulent strain, polymerase chain reaction ribotype 078. Clin Infect Dis 47:1162-1170
25. McDonald LC, Coignard B, Dubberke E, Song X, Horan T, Kutty PK; Ad Hoc Clostridium difficile Surveillance Working Group (2007) Recommendations for surveillance of Clostridium difficileassociated disease. Infect Control Hosp Epidemiol 28:140-145

26. Zar FA, Bakkanagari SR, Moorthi KM, Davis MB (2007) A comparison of vancomycin and metronidazole for the treatment of Clostridium difficile-associated diarrhea, stratified by disease severity. Clin Infect Dis 45:302-307

27. Clements AC, Magalhães RJ, Tatem AJ, Paterson DL, Riley TV (2010) Clostridium difficile PCR ribotype 027: assessing the risks of further worldwide spread. Lancet Infect Dis 10:395-404

28. Borgmann S, Kist M, Jakobiak T, Reil M, Scholz E, Von EichelStreiber C, Gruber H, Brazier JS, Schulte B (2008) Increased number of Clostridium difficile infections and prevalence of Clostridium difficile PCR ribotype 001 in southern Germany. Euro Surveill 13:pii=19057

29. Fawley WN, Parnell P, Verity P, Freeman J, Wilcox MH (2005) Molecular epidemiology of endemic Clostridium difficile infection and the significance of subtypes of the United Kingdom epidemic strain (PCR ribotype 1). J Clin Microbiol 43:2685-2696

30. Spigaglia P, Barbanti F, Dionisi AM, Mastrantonio P (2010) Clostridium difficile isolates resistant to fluoroquinolones in Italy: emergence of PCR ribotype 018. J Clin Microbiol 48:2892-2896

31. Fawley WN, Underwood S, Freeman J, Baines SD, Saxton K, Stephenson K, Owens RC Jr, Wilcox MH (2007) Efficacy of hospital cleaning agents and germicides against epidemic Clostridium difficile strains. Infect Control Hosp Epidemiol 28:920 925

32. Alfa MJ, Dueck C, Olson N, Degagne P, Papetti S, Wald A, Lo E, Harding G (2008) UV-visible marker confirms that environmental persistence of Clostridium difficile spores in toilets of patients with $C$. difficile-associated diarrhea is associated with lack of compliance with cleaning protocol. BMC Infect Dis 8:64

33. Dubberke ER, Reske KA, Noble-Wang J, Thompson A, Killgore G, Mayfield J, Camins B, Woeltje K, McDonald JR, McDonald LC, Fraser VJ (2007) Prevalence of Clostridium difficile environmental contamination and strain variability in multiple health care facilities. Am J Infect Control 35:315-318

34. Akerlund T, Svenungsson B, Lagergren A, Burman LG (2006) Correlation of disease severity with fecal toxin levels in patients with Clostridium difficile-associated diarrhea and distribution of PCR ribotypes and toxin yields in vitro of corresponding isolates. J Clin Microbiol 44:353-358

35. Underwood S, Guan S, Vijayasubhash V, Baines SD, Graham L, Lewis RJ, Wilcox MH, Stephenson K (2009) Characterization of the sporulation initiation pathway of Clostridium difficile and its role in toxin production. J Bacteriol 191:7296-7305

36. Kyne L, Warny M, Qamar A, Kelly CP (2000) Asymptomatic carriage of Clostridium difficile and serum levels of IgG antibody against toxin A. N Engl J Med 342:390-397

37. Warny M, Vaerman JP, Avesani V, Delmée M (1994) Human antibody response to Clostridium difficile toxin $\mathrm{A}$ in relation to clinical course of infection. Infect Immun 62:384-389

38. Gaynes R, Rimland D, Killum E, Lowery HK, Johnson TM 2nd, Killgore G, Tenover FC (2004) Outbreak of Clostridium difficile infection in a long-term care facility: association with gatifloxacin use. Clin Infect Dis 38:640-645

39. McCusker ME, Harris AD, Perencevich E, Roghmann MC (2003) Fluoroquinolone use and Clostridium difficile-associated diarrhea. Emerg Infect Dis 9:730-733

40. Pépin J, Saheb N, Coulombe MA, Alary ME, Corriveau MP, Authier S, Leblanc M, Rivard G, Bettez M, Primeau V, Nguyen M, Jacob CE, Lanthier L (2005) Emergence of fluoroquinolones as the predominant risk factor for Clostridium difficile-associated diarrhea: a cohort study during an epidemic in Quebec. Clin Infect Dis 41:1254-1260 
41. Yip C, Loeb M, Salama S, Moss L, Olde J (2001) Quinolone use as a risk factor for nosocomial Clostridium difficile-associated diarrhea. Infect Control Hosp Epidemiol 22:572-575

42. Coia JE (2009) What is the role of antimicrobial resistance in the new epidemic of Clostridium difficile? Int J Antimicrob Agents 33 (Suppl 1):S9-S12

43. Cheng VC, Tai JW, Chan WM, Lau EH, Chan JF, To KK, Li IW, Ho PL, Yuen KY (2010) Sequential introduction of single room isolation and hand hygiene campaign in the control of methicillin-resistant Staphylococcus aureus in intensive care unit. BMC Infect Dis 10:263

44. Linder JA, Huang ES, Steinman MA, Gonzales R, Stafford RS (2005) Fluoroquinolone prescribing in the United States: 1995 to 2002. Am J Med 118:259-268

45. Cheng VC, To KK, Li IW, Tang BS, Chan JF, Kwan S, Mak R, Tai J, Ching P, Ho PL, Seto WH (2009) Antimicrobial stewardship program directed at broad-spectrum intravenous antibiotics prescription in a tertiary hospital. Eur J Clin Microbiol Infect Dis 28:1447-1456

46. Muto CA, Blank MK, Marsh JW, Vergis EN, O’Leary MM, Shutt KA, Pasculle AW, Pokrywka M, Garcia JG, Posey K, Roberts TL, Potoski BA, Blank GE, Simmons RL, Veldkamp P, Harrison LH, Paterson DL (2007) Control of an outbreak of infection with the hypervirulent Clostridium difficile BI strain in a university hospital using a comprehensive "bundle" approach. Clin Infect Dis 45:1266-1273

47. Clabots CR, Shanholtzer CJ, Peterson LR, Gerding DN (1987) In vitro activity of efrotomycin, ciprofloxacin, and six other antimicrobials against Clostridium difficile. Diagn Microbiol Infect Dis 6:49-52

48. Dzink J, Bartlett JG (1980) In vitro susceptibility of Clostridium difficile isolates from patients with antibiotic-associated diarrhea or colitis. Antimicrob Agents Chemother 17:695-698
49. Hecht DW, Galang MA, Sambol SP, Osmolski JR, Johnson S, Gerding DN (2007) In vitro activities of 15 antimicrobial agents against 110 toxigenic Clostridium difficile clinical isolates collected from 1983 to 2004. Antimicrob Agents Chemother 51:2716-2719

50. Jabbar U, Leischner J, Kasper D, Gerber R, Sambol SP, Parada JP, Johnson S, Gerding DN (2010) Effectiveness of alcohol-based hand rubs for removal of Clostridium difficile spores from hands. Infect Control Hosp Epidemiol 31:565-570

51. Oughton MT, Loo VG, Dendukuri N, Fenn S, Libman MD (2009) Hand hygiene with soap and water is superior to alcohol rub and antiseptic wipes for removal of Clostridium difficile. Infect Control Hosp Epidemiol 30:939-944

52. Cheng VC, Wu AK, Cheung CH, Lau SK, Woo PC, Chan KH, Li KS, Ip IK, Dunn EL, Lee RA, Yam LY, Yuen KY (2007) Outbreak of human metapneumovirus infection in psychiatric inpatients: implications for directly observed use of alcohol hand rub in prevention of nosocomial outbreaks. J Hosp Infect 67:336-343

53. Wilcox MH, Fawley WN (2000) Hospital disinfectants and spore formation by Clostridium difficile. Lancet 356:1324

54. Stubbs SL, Brazier JS, O'Neill GL, Duerden BI (1999) PCR targeted to the 16S-23S rRNA gene intergenic spacer region of Clostridium difficile and construction of a library consisting of 116 different PCR ribotypes. J Clin Microbiol 37:461-463

55. Fenner L, Frei R, Gregory M, Dangel M, Stranden A, Widmer AF (2008) Epidemiology of Clostridium difficile-associated disease at University Hospital Basel including molecular characterisation of the isolates 2006-2007. Eur J Clin Microbiol Infect Dis 27:12011207

56. Muto CA (2007) Asymptomatic Clostridium difficile colonization: is this the tip of another iceberg? Clin Infect Dis 45:999-1000 